Article

\title{
Computational Study of Drugs Targeting Nuclear Receptors
}

\author{
Maša Kenda and Marija Sollner Dolenc *(D) \\ Faculty of Pharmacy; University of Ljubljana, Aškerčeva cesta 7, SI-1000 Ljubljana, Slovenia; \\ masa.kenda@ffa.uni-lj.si \\ * Correspondence: marija.sollner@ffa.uni-lj.si; Tel.: +386-1-476-9572
}

Academic Editor: Marjan Vračko

Received: 14 March 2020; Accepted: 31 March 2020; Published: 1 April 2020

\begin{abstract}
Endocrine-disrupting chemicals have been shown to interfere with the endocrine system function at the level of hormone synthesis, transport, metabolism, binding, action, and elimination. They are associated with several health problems in humans: obesity, diabetes mellitus, infertility, impaired thyroid and neuroendocrine functions, neurodevelopmental problems, and cancer are among them. As drugs are chemicals humans can be frequently exposed to for longer periods of time, special emphasis should be put on their endocrine-disrupting potential. In this study, we conducted a screen of 1046 US-approved and marketed small-molecule drugs (molecular weight between 60 and $600)$ for estimating their endocrine-disrupting properties. Binding affinity to 12 nuclear receptors was assessed with a molecular-docking program, Endocrine Disruptome. We identified 130 drugs with a high binding affinity to a nuclear receptor that is not their pharmacological target. In a subset of drugs with predicted high binding affinities to a nuclear receptor with Endocrine Disruptome, the positive predictive value was 0.66 when evaluated with in silico results obtained with another molecular docking program, VirtualToxLab, and 0.32 when evaluated with in vitro results from the Tox21 database. Computational screening was proven useful in prioritizing drugs for in vitro testing. We suggest that the novel interactions of drugs with nuclear receptors predicted here are further investigated.
\end{abstract}

Keywords: endocrine-disrupting chemicals; drugs; databases; nuclear receptors; molecular docking; multidimensional QSAR.

\section{Introduction}

Endocrine-disrupting chemicals (EDCs) are a subject of an increasing concern in our society. Exposure to them has been lined with obesity, diabetes mellitus, infertility, impaired thyroid and neuroendocrine functions, neurodevelopmental problems, and cancer [1]. The United States Environmental Protection Agency (USEPA) defines an endocrine-disrupting chemical (EDC) as "an exogenous agent that interferes with the production, release, transport, metabolism, binding, action, or elimination of natural hormones in the body responsible for the maintenance of homeostasis and the regulation of developmental processes" [2], while the World Health Organization (WHO) defines it as "an exogenous substance or mixture that alters function(s) of the endocrine system and consequently causes adverse effects in an intact organism, or its progeny, or (sub)populations" [3]. In 2016, the European Commission proposed an EDC definition to include known adverse effects "in an intact organism, or its progeny, or (sub)populations" [4]. The proposed change would mean some chemicals would not withstand the novel definition but would be classified as EDCs by the current one. Moreover, proposed criteria included a requirement to show EDC's health effects on human data, the obtaining of which is lengthier and more expensive than obtaining data with currently used alternative methods [4]. The request for human data would make it merely impossible to define any novel chemical as an EDC. 
Though the proposed criteria were not implemented, the need to develop better alternative methods for the identification of EDCs remains.

The most well-known mechanism of action of EDCs is their ability to act as agonists and antagonists of nuclear hormone receptors. Upon binding of a ligand to a nuclear receptor, the receptor homo- or heterodimerizes and is translocated in the cell nucleus where it acts as a transcription factor regulating a vast number of genes and eliciting numerous physiological responses. Among such receptors are androgen receptor (AR); estrogen receptors $\alpha(\mathrm{ER} \alpha)$ and $\beta(\mathrm{ER} \beta)$; glucocorticoid receptor (GR); liver $X$ receptors $\alpha(\mathrm{LXR} \alpha)$ and $\beta(\mathrm{LXR} \beta)$; peroxisome proliferator-activated receptors $\alpha(\operatorname{PPAR} \alpha), \beta(\operatorname{PPAR} \beta)$, and $\gamma(\operatorname{PPAR} \gamma)$; retinoid $X$ receptor $\alpha(\mathrm{RXR} \alpha)$; and thyroid receptors $\alpha(\mathrm{TR} \alpha)$ and $\beta(\mathrm{TR} \beta)$. Activation of those receptors regulates processes important for reproductive and developmental health, behavior, and the immune system [1]. The adverse outcome pathway (AOP) is a conceptual framework used in toxicological risk assessment. It is a sequence of events in a biological system that leads to an adverse outcome. The adverse outcome pathway starts with a molecular initiating event, defined as "the initial interaction between a molecule and a biomolecule or biosystem that can be causally linked to an outcome via a pathway", and is followed by several downstream key events, causing an adverse outcome [5]. Binding to a nuclear receptor is a molecular initiating event in several AOPs developed by the Organisation for Economic Co-operation and Development (OECD), e.g., "The AOP on Upregulation of Thyroid Hormone Catabolism via Activation of Hepatic Nuclear Receptors, and Subsequent Adverse Neurodevelopmental Outcomes in Mammals", "The AOPs Linking Aromatase Inhibition, Androgen Receptor Agonism, Estrogen Receptor Antagonism, or Steroidogenesis Inhibition, to Impaired Reproduction in Small Repeat-Spawning Fish Species", and "The AOP on CAR and PPAR $\alpha$-mediated pathways to non-genotoxic rodent liver cancer" [6]. Ligand binding of an EDC to a nuclear receptor could be considered as a molecular initiating event for many endocrine-related adverse outcomes in the future.

As drugs are chemicals we are frequently exposed to on a daily basis, in some cases for longer periods (up to a lifetime), and in higher quantities compared to other groups of EDCs (e.g., flame retardants, cosmetic ingredients, and plasticizers), special emphasis should be put on their endocrine-disrupting potential. In addition to known and well-documented exposure, pharmacologically active substances and/or their metabolites are also present in the environment (e.g., surface and drinking water and soil) and can enter the food chain (e.g., via meat produce, fish, and crops) [7-9]. In 2018, the European Medicines Agency issued a draft of revised guidelines on the environmental risk assessment of medicinal products for human use, which requires data on the effects on development and reproduction (including data on interacting or interfering with endocrine receptors) for all human drugs submitted for marketing authorization [10].

In this study, we set out to screen US-approved and marketed small-molecule drugs for endocrine-disrupting potential, using docking to nuclear receptors with Endocrine Disruptome (ED) - a program developed by our research group. Docking to nuclear receptors with VirtualToxLab (VTL) and data on the in vitro activity of drugs from in the Tox21 database will be used for assessing the positive predictive value (PPV) of ED.

\section{Results}

Molecular docking with ED was used to predict the binding of US-approved and marketed small-molecule drugs from the NCATS (National Center for Advancing Translational Sciences) Inxight: Drugs portal (version 1.1) to nuclear receptors [11,12]. Due to limitations of the ED (described in Section 4. Materials and Methods), 3.6\% of the initial database entries were omitted, and a total of 1046 drugs were considered. Results where strong binding to a nuclear receptor was predicted were further evaluated by another in silico docking tool, VTL, and with in vitro data on reporter cell lines from the Tox21 database [13-17]. 


\subsection{Screening of US-Approved and Marketed Drugs with ED}

\subsubsection{Binding Affinity Distribution Across Nuclear Receptors}

The results of the predicted binding affinity distribution with ED for 1046 across 12 nuclear receptors are shown in Figure 1. Results are color-coded; green corresponds to a low probability of binding, yellow and orange correspond to a medium probability of binding, and red corresponds to a high probability of binding. Out of 1046 drugs tested, 22 exerted strong binding for the agonist conformation of AR, 51 for the antagonist conformation of AR, 47 for the agonist conformation of ER $\alpha$, 24 for the antagonist conformation of $E R \alpha, 14$ for the agonist conformation of $E R \beta, 62$ for the antagonist conformation of ER $\beta, 4$ for the agonist conformation of GR, 22 for the antagonist conformation of GR, 6 for $\mathrm{LXR} \alpha, 14$ for $\mathrm{LXR} \beta, 11$ for PPAR $\alpha, 15$ for PPAR $\beta, 15$ for PPAR $\gamma, 1$ for RXR $\alpha, 3$ for TR $\alpha$, and 6 for TR $\beta$. The most frequently bound receptors are therefore ER $\beta$ with $7.3 \%$ of the predicted strong binders among the screened drugs, followed by AR with $7.0 \%$ of the predicted strong binders among the screened drugs, and ER $\alpha$ with $6.8 \%$ of the predicted strong binders among the screened drugs. A complete list of 1046 drugs tested in this study with results for each receptor is available in Table S1: US-approved and marketed drugs with Endocrine Disruptome (ED)-predicted binding to respective nuclear receptors.

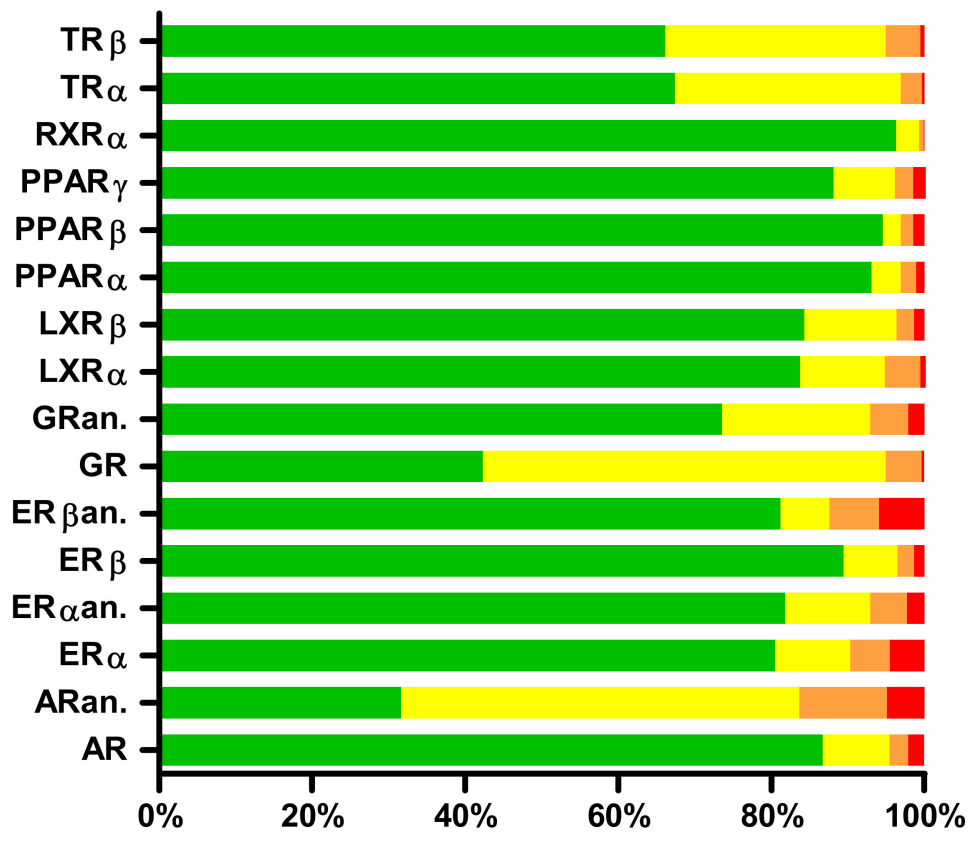

Figure 1. Binding affinity distribution of 1046 tested drugs for 12 nuclear receptors as assayed with Endocrine Disruptome. Green corresponds to a low probability of binding, yellow and orange correspond to a medium probability of binding, and red corresponds to a high probability of binding [12]. $\mathrm{AR}$-agonist conformation of androgen receptor; ARan—antagonist conformation of androgen receptor; $\mathrm{ER} \alpha$-agonist conformation of estrogen receptor $\alpha$; ER $\alpha \mathrm{an}$-antagonist conformation of estrogen receptor $\alpha$; ER $\beta$-agonist conformation of estrogen receptor $\beta$; ER $\beta$-antagonist conformation of estrogen receptor $\beta$; GR-agonist conformation of glucocorticoid receptor; GR-antagonist conformation of glucocorticoid receptor; $\operatorname{LXR} \alpha$-liver $X$ receptor $\alpha$; LXR $\beta$-liver $X$ receptor $\beta$; $\operatorname{PPAR} \alpha$ - peroxisome proliferator-activated receptor $\alpha$; PPAR $\beta$-peroxisome proliferator-activated receptor $\beta$; PPAR $\gamma$-peroxisome proliferator-activated receptor $\gamma ; \operatorname{RXR} \alpha$-retinoid X receptor $\alpha$; TR $\alpha$-thyroid receptor $\alpha$; TR $\beta$-thyroid receptor $\beta$.

\subsubsection{Identification of Drugs with Strong Binding to Nuclear Receptors}

In the next step, we removed drugs that work pharmacologically by binding to a nuclear receptor (i.e., drugs of Anatomical Therapeutic Chemical (ATC) Classification System groups “D07 
Corticosteroids, dermatological preparations"; "L02 Endocrine therapy"; "G02 Other gynecologicals"; "G03 Genito-urinary system and sex hormones"; and retinoids from group "D Dermatologicals" were excluded). The remaining strong binders (130) and the receptors they bind to are listed in Table 1. For simplicity, we will further refer to this list as "prioritized drugs".

Table 1. Medicines with Endocrine Disruptome-predicted strong binding to respective nuclear receptors.

\begin{tabular}{|c|c|c|}
\hline Name $^{1}$ & Nuclear Receptor ${ }^{2}$ & Binding Free Energy (kcal/mol) \\
\hline Amitriptyline & $\mathrm{ER} \beta$ & $-9.2_{(\mathrm{an})}$ \\
\hline Amoxicillin & $\mathrm{AR}$ & $-8.5_{(\mathrm{an})}$ \\
\hline Apixaban & $\operatorname{PPAR} \gamma$ & -10.5 \\
\hline Aprepitant & GR; LXR $\beta ;$ PPAR $\gamma$ & $-10.0_{(\text {an })} ;-12.4$ \\
\hline Artemether & $\mathrm{AR} ; \mathrm{ER} \beta$ & $-8.7_{(\mathrm{an})} ;-9.6$ \\
\hline Asenapine & $\mathrm{ER} \alpha$ & -9.6 \\
\hline Atovaquone & $\mathrm{GR} ; \mathrm{LXR} \alpha ; \mathrm{LXR} \beta ; \mathrm{TR} \beta$ & $-11.0 ;-12.2 ;-12.4 ;-10.8$ \\
\hline Axitinib & GR & -10.8 \\
\hline Azilsartan & $\mathrm{ER} \beta ; \mathrm{GR}$ & $-9.8_{(\mathrm{an})} ;-9.9_{(\mathrm{an})}$ \\
\hline Belinostat & $\mathrm{TR} \alpha$ & -10.5 \\
\hline Benzatropine & $\mathrm{ER} \alpha ; \mathrm{ER} \beta$ & $-9.6 ;-9.6_{(\text {an })}$ \\
\hline Brexpiprazole & $\mathrm{ER} \alpha$ & -9.4 \\
\hline Butenafine & $\mathrm{ER} \beta$ & $-9.6_{(\text {an })}$ \\
\hline Butorphanol & $\mathrm{ER} \alpha$ & -9.3 \\
\hline Cabozantinib & $\mathrm{ER} \beta ; \mathrm{GR}$ & $-9.1_{(\mathrm{an})} ;-10.2_{(\mathrm{an})}$ \\
\hline Candesartan & $E R \beta$ & $-9.6_{(\mathrm{an})}$ \\
\hline Carbamazepine & $\mathrm{AR} ; \mathrm{ER} \alpha ; \mathrm{ER} \beta$ & $-8.8_{(\mathrm{an})} ;-9.6 ;-9.8_{(\mathrm{an})}$ \\
\hline Celecoxib & $\mathrm{ER} \alpha ; \mathrm{ER} \beta$ & -9.6 and $-9.9_{(\mathrm{an})} ;-9.3$ \\
\hline Ceritinib & $\mathrm{ER} \beta$ & $-9.2_{(\mathrm{an})}$ \\
\hline Cinacalcet & $\mathrm{AR} ; \mathrm{ER} \alpha ; \mathrm{ER} \beta ; \mathrm{TR} \alpha$ & $-8.5_{(\mathrm{an})} ;-10.0 ;-9.7$ and $-9.2_{(\mathrm{an})} ;-10.3$ \\
\hline Clonazepam & $E R \beta$ & $-9.4_{(\mathrm{an})}$ \\
\hline Clorazepate & $\mathrm{ER} \alpha$ & -9.4 \\
\hline Cocaine & $\mathrm{AR}$ & $-8.4_{(\mathrm{an})}$ \\
\hline Codeine & $\mathrm{AR}$ & -9.1 and $-8.7_{(\mathrm{an})}$ \\
\hline Conivaptan & $\mathrm{ER} \beta ; \mathrm{GR}$ & $-9.5 ;-10.9$ and $-11.1_{(\text {an })}$ \\
\hline Cyclobenzaprine & $\mathrm{AR} ; \mathrm{ER} \alpha ; \mathrm{ER} \beta$ & $-8.6_{(\mathrm{an})} ;-9.9 ;-9.6_{(\mathrm{an})}$ \\
\hline Cyproheptadine & $\mathrm{ER} \alpha ; \mathrm{ER} \beta$ & $-10.2 ;-9.3_{(\text {an })}$ \\
\hline Dabrafenib & $\mathrm{ER} \beta$ & $-9.7_{(\text {an })}$ \\
\hline Dacomitinib & GR & $-9.6_{(\mathrm{an})}$ \\
\hline Darifenacin & $\mathrm{ER} \alpha$ & -9.7 \\
\hline Deacetylbisacodyl & $E R \alpha ; E R \beta$ & $-9.5 ;-9.4_{(\mathrm{an})}$ \\
\hline Deferasirox & $\mathrm{ER} \alpha$ & $-9.4_{(\mathrm{an})}$ \\
\hline Diazepam & $\mathrm{ER} \alpha$ & $-9.5^{(\text {ant }}$ \\
\hline Dihydroergotamine & $\mathrm{ER} \alpha ; \mathrm{ER} \beta ; \mathrm{GR}$ & $-11.6_{(\mathrm{an})} ;-10.6_{(\mathrm{an})} ;-11.6_{(\mathrm{an})}$ \\
\hline Duvelisib & $\mathrm{ER} \beta ; \mathrm{LXR} \alpha ; \mathrm{LXR} \beta$ & $-9.2_{(\mathrm{an})} ;-12.5 ;-12.5$ \\
\hline Efinaconazole & $\mathrm{AR}$ & $-8.9_{(\text {an })}$ \\
\hline Eltrombopag & $\mathrm{ER} \alpha ; \mathrm{LXR} \alpha ; \mathrm{LXR} \beta$ & $-9.9_{(\mathrm{an})} ;-12.4 ;-12.3$ \\
\hline Entecavir & $\mathrm{AR}$ & -8.5 \\
\hline Ergotamine & GR & $-11.3_{(\text {an })}$ \\
\hline Eslicarbazepine & $\mathrm{ER} \alpha$ & -9.9 \\
\hline Estazolam & $\mathrm{ER} \beta$ & $-9.1_{(\mathrm{an})}$ \\
\hline Ezetimibe & $\mathrm{ER} \alpha ; \mathrm{ER} \beta ; \mathrm{PPAR} \gamma$ & -10.5 and $-9.8_{(\mathrm{an})} ;-9.7_{(\mathrm{an})} ;-10.7$ \\
\hline Fenoldopam & $\mathrm{AR}$ & $-8.9_{(\text {an })}$ \\
\hline Fentanyl & $\mathrm{AR}$ & $-8.8($ an) \\
\hline Fexofenadine & $\mathrm{ER} \alpha$ & -9.4 \\
\hline Flavoxate & $\mathrm{ER} \alpha$ & -9.6 \\
\hline Flumazenil & $\mathrm{AR}$ & $-8.5_{(\mathrm{an})}$ \\
\hline Fluorescein & $\mathrm{ER} \beta$ & $-9.7_{(\mathrm{an})}$ \\
\hline Fluoxetine & $\mathrm{AR}$ & $-8.5($ an) \\
\hline
\end{tabular}


Table 1. Cont.

\begin{tabular}{|c|c|c|}
\hline Name ${ }^{1}$ & Nuclear Receptor $^{2}$ & Binding Free Energy (kcal/mol) \\
\hline Glimepiride & $\mathrm{ER} \alpha$ & -10.0 \\
\hline Glipizide & $\mathrm{ER} \alpha$ & -9.4 and $-9.4_{(\text {an })}$ \\
\hline Glyburide/glibenclamide & $\mathrm{ER} \alpha$ & -9.4 \\
\hline Granisetron & $\mathrm{AR}$ & $-8.8_{(\text {an })}$ \\
\hline Hydrocodone & $\mathrm{AR}$ & $-8.7_{(\mathrm{an})}$ \\
\hline Hydromorphone & $\mathrm{AR} ; \mathrm{ER} \alpha ; \mathrm{ER} \beta$ & $-9.2_{(\mathrm{an})} ;-9.8 ;-9.4$ and $-9.5_{(\mathrm{an})}$ \\
\hline Ibrutinib & GR; LXR $\beta ;$ PPAR $\gamma$ & $-9.9(\mathrm{an}) ;-12.7 ;-10.5$ \\
\hline Imatinib & $\mathrm{ER} \alpha$ & $-9.8_{(\mathrm{an})}$ \\
\hline Indapamide & $\mathrm{ER} \alpha$ & $-9.5($ an $)$ \\
\hline Irbesartan & $\mathrm{ER} \alpha ; \mathrm{ER} \beta$ & $-10.0_{(\mathrm{an})} ;-9.4_{(\mathrm{an})}$ \\
\hline Irinotecan & $\mathrm{ER} \alpha ; \mathrm{ER} \beta ; \mathrm{GR}$ & $-9.4_{(\mathrm{an})} ;-9.7_{(\mathrm{an})} ;-11.1_{(\mathrm{an})}$ \\
\hline Ketoconazole & $\mathrm{ER} \alpha ; \mathrm{ER} \beta$ & -9.5 and $-9.9_{(\mathrm{an})} ;-9.3_{(\mathrm{an})}$ \\
\hline Ketorolac & $\mathrm{AR}$ & $-8.5_{(\text {an })}$ \\
\hline Lapatinib & $\operatorname{PPAR} \gamma$ & -11.0 \\
\hline Larotrectinib & $\mathrm{ER} \beta ; \mathrm{LXR} \beta$ & $-9.1_{(\mathrm{an})} ;-12.2$ \\
\hline Levorphanol & $\mathrm{AR} ; \mathrm{ER} \alpha ; \mathrm{ER} \beta$ & -9.1 and $-8.9_{(\mathrm{an})} ;-9.5 ;-9.5$ and $-9.1_{(\mathrm{an})}$ \\
\hline Lorazepam & $\mathrm{ER} \beta$ & -9.6 \\
\hline Lumacaftor & $\mathrm{ER} \beta ; \mathrm{GR} ; \mathrm{LXR} \beta$ & $-9.9_{(\mathrm{an})} ;-10.3_{(\mathrm{an})} ;-12.7$ \\
\hline Lurasidone & $\mathrm{ER} \beta ; \mathrm{GR} ; \mathrm{LXR} \alpha ; \mathrm{LXR} \beta$ & $-9.2_{(\mathrm{an})} ;-10.0_{(\mathrm{an})} ;-12.1 ;-12.6$ \\
\hline Maprotiline & $\mathrm{ER} \alpha$ & -9.6 \\
\hline Maraviroc & $\mathrm{ER} \alpha ; \mathrm{ER} \beta$ & $-9.4_{(\mathrm{an})} ;-9.7_{(\mathrm{an})}$ \\
\hline Meclizine & $\mathrm{ER} \beta$ & $-9.3_{(\mathrm{an})}$ \\
\hline Meclofenamic acid & $\mathrm{AR}$ & $-8.5($ an) \\
\hline Mefloquine & $\mathrm{AR} ; \mathrm{ER} \beta ; \mathrm{TR} \alpha$ & $-9.8_{(\mathrm{an})} ;-9.4_{(\mathrm{an})} ;-10.5$ \\
\hline Methscopolamine & $\mathrm{AR}$ & $-8.5_{(\mathrm{an})}$ \\
\hline Methylnaltrexone & $\mathrm{TR} \beta$ & -10.6 \\
\hline Montelukast & $\mathrm{ER} \alpha ; \mathrm{ER} \beta ; \mathrm{PPAR} \gamma$ & $-10.2_{(\mathrm{an})} ;-9.5_{(\mathrm{an})} ;-10.4$ \\
\hline Morphine & $\mathrm{ER} \alpha ; \mathrm{ER} \beta$ & $-9.4 ;-9.5$ \\
\hline Naftifine & $\mathrm{AR} ; \mathrm{ER} \beta$ & $-8.7_{(\mathrm{an})} ;-9.5$ \\
\hline Naldemedine & $\mathrm{ER} \beta ; \mathrm{GR}$ & $-9.2_{(\mathrm{an})} ;-10.8_{(\mathrm{an})}$ \\
\hline Naltrexone & $\mathrm{AR}$ & $-8.7_{(\text {an })}$ \\
\hline Nebivolol & $\mathrm{AR} ; \mathrm{ER} \alpha$ & $-8.7_{(\mathrm{an})} ;-9.5$ and $-9.5_{(\mathrm{an})}$ \\
\hline Nelfinavir & $\mathrm{ER} \alpha ; \mathrm{ER} \beta ; \mathrm{GR} ; \mathrm{PPAR} \gamma$ & $-10.5_{(\mathrm{an})} ;-9.6_{(\mathrm{an})} ;-10.9_{(\mathrm{an})} ;-11.5$ \\
\hline Netupitant & GR & $-10.8_{(\text {an })}$ \\
\hline Nintedanib & GR & $-10.0_{(\mathrm{an})}$ \\
\hline Nitisinone & $\mathrm{AR}$ & $-8.9(\mathrm{an})$ \\
\hline Nortriptyline & $\mathrm{ER} \beta$ & $-9.1_{(\mathrm{an})}$ \\
\hline Olaparib & GR; LXR $\beta$ & $-10.7_{(a n)} ;-12.9$ \\
\hline Olopatadine & $\mathrm{AR} ; \mathrm{ER} \alpha$ & $-8.7_{(\mathrm{an})} ;-9.5$ \\
\hline Oxazepam & $\mathrm{ER} \beta$ & -9.4 \\
\hline Oxcarbazepine & $\mathrm{ER} \alpha$ & -9.9 \\
\hline Oxymorphone & $\mathrm{AR} ; \mathrm{ER} \beta$ & $-9.0_{(\mathrm{an})} ;-9.4$ and $-9.2_{(\mathrm{an})}$ \\
\hline Palbociclib & GR & -9.9 (an) \\
\hline Paliperidone & $\mathrm{ER} \alpha$ & $-9.6_{(\text {an })}$ \\
\hline Palonosetron & $\mathrm{AR} ; \mathrm{ER} \alpha$ & -10.0 and $-9.3_{(a n)} ;-9.6$ \\
\hline Paroxetine & $\mathrm{ER} \alpha$ & -9.5 \\
\hline Penicillin g/benzylpenicillin & $\mathrm{AR}$ & $-8.5_{(\mathrm{an})}$ \\
\hline Perampanel & $\mathrm{ER} \beta$ & $-9.6_{(\text {an })}$ \\
\hline Phenindamine & $\mathrm{ER} \alpha ; \mathrm{ER} \beta$ & $-9.6 ;-9.5$ and $-9.7_{(\text {an })}$ \\
\hline Pimozide & $\begin{array}{l}\text { ER } \alpha ; E R \beta ; \text { GR; LXR } \alpha ; \mathrm{LXR} \beta ; \\
\text { PPAR } \gamma\end{array}$ & $\begin{array}{l}-9.9 ;-9.9(\mathrm{an}) ;-10.6_{(\mathrm{an})} ;-12.1 ;-12.8 \\
-11.2\end{array}$ \\
\hline Piroxicam & $\mathrm{AR}$ & -9.3 and $-9.0_{(\mathrm{an})}$ \\
\hline Plerixafor & $\mathrm{ER} \alpha ; \mathrm{ER} \beta$ & $-10.8_{(\mathrm{an})} ;-10.9_{(\mathrm{an})}$ \\
\hline Pomalidomide & $\mathrm{AR}$ & -8.7 \\
\hline
\end{tabular}


Table 1. Cont.

\begin{tabular}{lll}
\hline Name ${ }^{1}$ & Nuclear Receptor ${ }^{2}$ & Binding Free Energy (kcal/mol) \\
\hline Ponatinib & GR; PPAR $\gamma$ & $-10.0_{(\mathrm{an})} ;-10.6$ \\
Protriptyline & ER $\beta$ & $-9.1_{(\mathrm{an})}$ \\
Regorafenib & ER $\alpha$ ER $\beta$ & $-10.0 ;-9.7_{(\mathrm{an})}$ \\
Revefenacin & ER $\beta ;$ GR; PPAR $\gamma$ & $-9.7_{(\mathrm{an})} ;-10.2_{(\mathrm{an})} ;-10.7$ \\
Risperidone & ER $\alpha ;$ ER $\beta ;$ LXR $\beta$ & $-9.7_{(\mathrm{an})} ;-9.5_{(\mathrm{an})} ;-12.3$ \\
Rolapitant & ER $\beta ;$ PPAR $\gamma ;$ TR $\beta$ & $-10.5_{(\mathrm{an})} ;-10.5 ;-10.8$ \\
Sertraline & ER $\alpha$ & -9.5 \\
Sitagliptin & ER $\alpha$ & -9.5 \\
Solifenacin & ER $\beta$ & $-9.6_{(\mathrm{an})}$ \\
Sonidegib & ER $\beta$ & $-9.5_{(\mathrm{an})}$ \\
Sorafenib & ER $\alpha$ & $-9.9_{(\mathrm{an})}$ \\
Tadalafil & ER $\alpha ;$ ER $\beta$ & $-9.7_{(\mathrm{an})} ;-9.6_{(\mathrm{an})}$ \\
Telmisartan & ER $\alpha ;$ ER $\beta ;$ PPAR $\gamma$ & $-10.0_{(\mathrm{an})} ;-10.1_{(\mathrm{an})} ;-10.6$ \\
Telotristat & PPAR $\gamma$ & -10.4 \\
Temazepam & ER $\alpha$ & -9.8 \\
Thalidomide & AR & -8.7 \\
Tolnaftate & ER $\alpha$ & -9.5 \\
Tolvaptan & ER $\beta ;$ GR & $-9.6_{(\mathrm{an})} ;-10.3_{(\mathrm{an})}$ \\
Triamterene & AR & -8.8 and $-9.0_{(\mathrm{an})}$ \\
Triazolam & ER $\beta$ & $-9.1_{(\mathrm{an})}$ \\
Trihexyphenidyl & AR; ER $\beta$ & $-9.0_{(\mathrm{an})} ;-9.3$ \\
Umeclidinium & ER $\alpha$ & -9.5 \\
Vilazodone & GR & -10.8 \\
Vorapaxar & ER $\beta ;$ GR & $-9.7_{(\mathrm{an})} ;-10.6_{(\mathrm{an})}$ \\
Voriconazole & AR & $-8.8_{(\mathrm{an})}$ \\
Vortioxetine & AR & $-8.5_{(\mathrm{an})}$ \\
Warfarin & ER $\alpha$ & $-9.4_{(\mathrm{an})}$ \\
Zafirlukast & ER $\beta ;$ PPAR $\gamma$ & $-9.7_{(\mathrm{an})} ;-10.9$ \\
\hline
\end{tabular}

${ }^{1}$ The table shows medicines that do not bind to a nuclear receptor as their pharmacological mode of action.

${ }^{2} \mathrm{AR}$-androgen receptor; $\mathrm{ER} \alpha$ - estrogen receptor; $\mathrm{ER} \beta$ - estrogen receptor $\beta$; GR-glucocorticoid receptor; $\mathrm{LXR} \alpha$-liver X receptor $\alpha$; LXR $\beta$-liver X receptor $\beta$; PPAR $\alpha$-peroxisome proliferator-activated receptor $\alpha$; PPAR $\beta$ - peroxisome proliferator-activated receptor $\beta$; PPAR $\gamma$-peroxisome proliferator-activated receptor $\gamma$; RXR $\alpha$-retinoid X receptor $\alpha$; TR $\alpha$ —thyroid receptor $\alpha$; TR $\beta$ —thyroid receptor $\beta$; an-antagonist conformation.

Prioritized drugs are represented in all ATC groups (Figure 2). The most represented groups are group "N, nervous system" with 39 drugs and group "L, antineoplastic and immunomodulating agents" with 22 drugs, followed by group "A, alimentary tract and metabolism" with 15 drugs and group " $C$, cardiovascular system" with 11 drugs. Other ATC groups have fewer than 10 drugs.

Further dissection of drugs in groups "L, antineoplastic and immunomodulating agents" and "N, nervous system" is presented in Figure 3. Group " $\mathrm{L}$, antineoplastic and immunomodulating agents" consists of 19 antineoplastic agents-out of which, 14 are tyrosine kinase inhibitors, with two immunosuppressants and an immunostimulant (Figure 3a). Group "N, nervous system" consists of 13 psycholeptics, 9 psychoanaleptics, 8 analgesics, 5 antiepileptics, 2 anti-Parkinson drugs, 2 anesthetics, and 1 other nervous system drug (Figure $3 \mathrm{~b}$ ). The most well-represented group among the psychoanaleptics are antidepressants-four of which are nonselective monoamine reuptake inhibitors, three are selective serotonin reuptake inhibitors, and two are other antidepressants. Additionally, there are seven benzodiazepine derivatives among the psycholeptics, belonging to subcategories of anxiolytics or hypnotics and sedatives. 


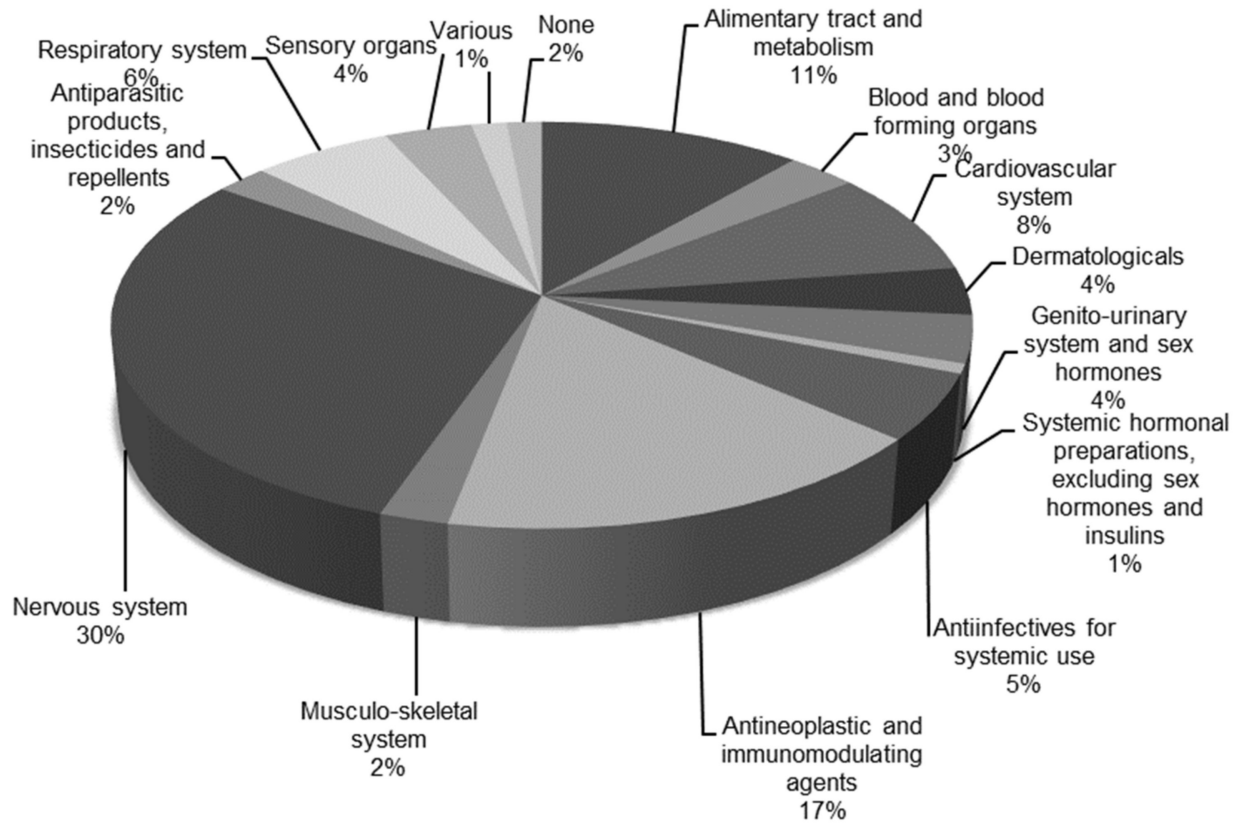

Figure 2. Distribution of prioritized drugs across the Anatomical Therapeutic Chemical (ATC) Classification System groups. Drugs that bind to a nuclear receptor as their mode of action were excluded. Total number of drugs represented in this figure is 130.

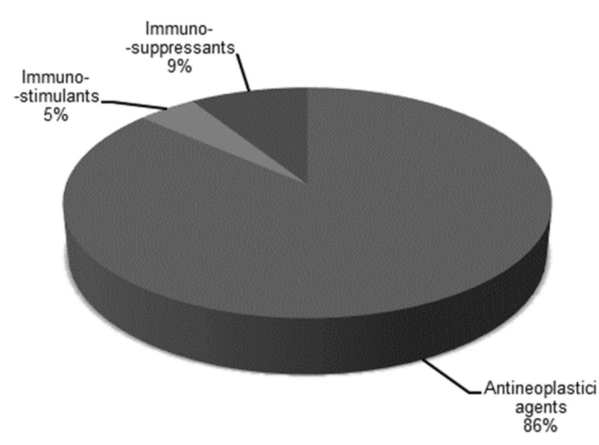

(a)

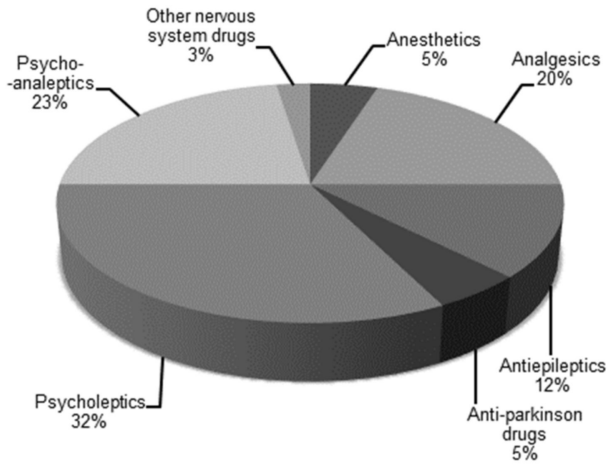

(b)

Figure 3. Distribution of prioritized drugs within the Anatomical Therapeutic Chemical (ATC) Classification System groups: (a) antineoplastic and immunomodulating agents and (b) the nervous system. Drugs that bind to a nuclear receptor as their mode of action were excluded. Total number of drugs represented in this figure is 22 in (a) and 39 in (b).

\subsection{Positive Predictive Value of ED Prediction}

Positive results for prioritized drugs were further evaluated with another docking in, silico tool, VTL, and with the in vitro results on reporter cell lines from the Tox21 database.

\subsubsection{Evaluation with VTL}

A subset of prioritized drugs was tested with VTL. The positive predictive value was calculated (Equation (1)):

$$
\mathrm{PPV}=\mathrm{TP} /(\mathrm{TP}+\mathrm{FP})
$$

where TP and FP represent true positives and false positives, respectively. A drug was considered a TP if the ED predicted strong binding to a nuclear receptor and binding to that receptor was predicted 
with VTL. A drug was considered a FP if the ED predicted strong binding to a nuclear receptor and VTL predicted "not binding" for that receptor.

The positive predictive value for prioritized drugs was 0.66 when evaluated with VTL.

\subsubsection{Evaluation with Tox21 Database}

Further, a subset of prioritized drugs was compared to in vitro results on reporter cell lines obtained from the Tox 21 database, if available. A total of 53 drug-receptor interactions for prioritized drugs were found in the Tox21 database, and a PPV of 0.32 was calculated (Equation (1)). A drug was considered a TP if the ED predicted strong binding to a nuclear receptor and the drug exerted activity in cell assays for that receptor. A drug was considered a FP if the ED predicted strong binding to a nuclear receptor and the drug exerted no activity in cell assays for that receptor.

\subsection{Cell-Based In Vitro Assays}

Two drugs, irinotecan and palonosetron, were tested in luciferase reporter cell lines for activity on GR in the MDA-kb2 cell line and for activity on AR in the AR-EcoScreen cell line. Endocrine Disruptome-predicted antagonism on GR was confirmed for irinotecan $\left(\mathrm{IC}_{50}=40.32 \mu \mathrm{M}\right.$; dose-response curve is shown in Figure 4a). For palonosetron, a modulation of AR was confirmed. Palonosetron is an antagonist on $\mathrm{AR}\left(\mathrm{IC}_{50}=18.65 \mu \mathrm{M}\right.$; dose-response curve is shown in Figure $\left.4 \mathrm{~b}\right)$, while it was tested negative at the highest noncytotoxic concentration of $10 \mu \mathrm{M}$ in an agonist assay in the AR-EcoScreen cell line (data not shown).

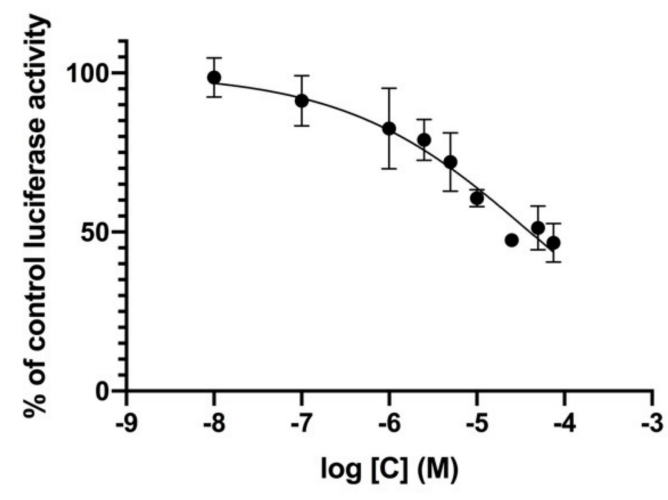

(a)

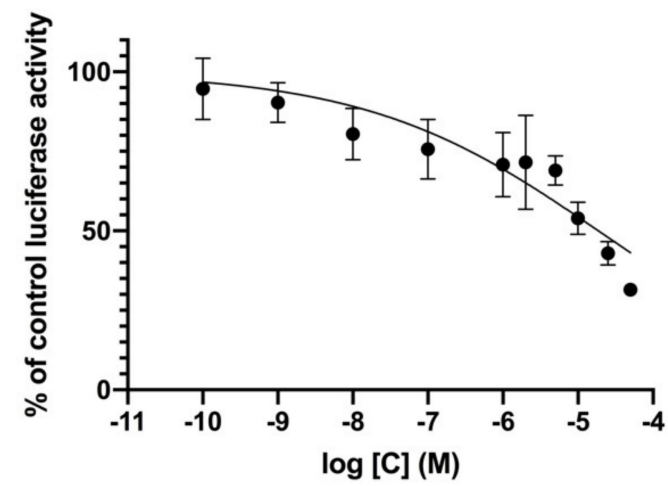

(b)

Figure 4. Dose-response curves for Endocrine Disruptome (ED)-predicted antagonist activities in luciferase reporter cell lines for: (a) irinotecan on GR in the MDA-kb2 cell line and (b) palonosetron on AR in the AR-EcoScreen cell line. Mean and SD of at least three independent experiments are shown.

\section{Discussion}

Both in silico tools used here are listed among the software tools for the in silico prediction of binding to nuclear receptors in guidance for the identification of endocrine disruptors by the European Chemical Agency and the European Food Safety Authority [18]. The guidance emphasizes the applicability of in silico predictions in providing information on molecular initiating events and making informed decisions on further testing strategies. The importance of considering the performance and applicability domain of in silico tools is stressed.

The ED tool was developed for the toxicological screening of new compounds; therefore, it was designed in a way to predict negative results with greater accuracy, as opposed to correctly predicting positive results [12]. Consequently, the program predicts fewer false negatives (FN), but there are more FP. Fewer FN assure a better safety assessment of new chemicals. Here, we used ED to find possible endocrine disruptors among the drugs. As positive results were searched for, we expected a low PPV 
(the ratio of true positives and all predicted positive results). Hence, validations of predicted positive results with another in silico tool, VTL, and in vitro results in the Tox21 database were performed.

Advantages of the ED as compared to VTL are that the ED is freely available via a web interface, the compound can easily be submitted by a simple SMILES input, and the calculation is quick. Limitations of the program in terms of the features of compounds that cannot be submitted to the ED are described in the Methods section. Conversely, VTL is not as easy to use, but it has an obvious and very valuable advantage over the ED-in addition to molecular modeling of the receptor interactions, VTL uses multidimensional QSAR modeling of the receptor-based activity, which yields quantitative binding information, i.e., a concentration at which an interaction with a nuclear receptor is predicted.

In addition to the ED having fewer false negatives at the cost of the PPV, as described above, the calculation of the PPV in this study has some limitations. VirtualToxLab is more advanced than the ED in terms of the computational background of both interfaces. We assumed VTL results as TP and TN, as it is known that false-positive results in the ED are yielded due to the program's preference to correctly predict negative results, while false-positive results in VTL are attributed only to pharmacokinetic effects [14]. Though, VTL is not necessarily more accurate than the ED, as false-negative results are known to emerge for very small compounds. To some extent, this was avoided by database preparation with a restriction on molecular weight, as described in the Methods section. Additionally, VTL does not discriminate against the agonist and antagonist conformations of receptors, and the interpretation of those results might be intricate. To exemplify, in the case of palonosetron ED-predicted binding to AR for both agonist and antagonist receptor conformations, while VTL predicted no binding to AR. Our in vitro experiments confirmed AR antagonism for palonosetron with $\mathrm{IC}_{50}$ of $18.65 \mu \mathrm{M}$, but ED-predicted AR agonism was not confirmed at the highest noncytotoxic concentration. Therefore, the PPV for the ED of 0.66, calculated from an evaluation with VTL, might, in fact, be higher.

A major limitation of the evaluation with in vitro results in the Tox 21 database is the possible cytotoxicity of the compounds. Though activity yielding due to cytotoxicity in antagonist-type assays was excluded from consideration, cytotoxicity might have caused some agonists to be interpreted as not active. Tox21 assays do not include OECD-validated cell lines AR-EcoScreen and hERalpha-HeLa-9903 for the identification of compounds with activity on AR and ER $\alpha$, respectively [19,20]. Additionally, active concentrations of a compound might be between two tested concentrations in Tox21 assays, i.e., between an inactive and a cytotoxic concentration. Therefore, a positive result would remain unnoticed. An example of this phenomenon might be a Tox21 result on the estrogenic activity of paroxetine-Tox21 high-throughput assays for the activity of paroxetine on the estrogen receptor, namely, assays tox21-er-bla-agonist-p2, tox21-er-bla-antagonist-p1, tox21-er-luc-bg1-4e2-agonist-p2, tox21-er-luc-bg1-4e2-antagonist-p1, and tox21-er-luc-bg1-4e2-antagonist-p2, did not identify any activity of paroxetine on the ER, while the agonist activity of 10 and $20-\mu \mathrm{M}$ paroxetine was shown in two ER-positive cell lines, MCF-7 and T47D, in a 96-well format [21]. Similarly, no antagonist activity of irinotecan on the GR at concentrations tested in the Tox21 assay tox21-gr-hela-bla-antagonist-p1 was seen, but we confirmed GR antagonism in the MDA-kb2 cell line with an $\mathrm{IC}_{50}$ of $18.65 \mu \mathrm{M}$. The difference in the outcomes is, hence, most likely due to more micromolar concentrations tested in our in vitro experiment. Another limitation of all cell-based assays is passing through the cell membrane. This could cause a lower concentration of a chemical at the nuclear receptor and result in a FP in our evaluation with in vitro results from the Tox 21 database. The number of FP in the PPV calculated from an evaluation with Tox21 might really be lower due to the shortcomings of Tox21 assays, and a PPV higher than 0.32 might be expected. On the other hand, compounds might inhibit the luciferase reporter gene used in Tox21 assays and produce false-positive results in antagonism-type cell-based assays or stabilize the luciferase reporter gene and produce false-positive results in agonism-type cell-based assays [22,23].

Another level of complexity in assessing the endocrine-disrupting potential of drugs is added when the question of toxicological relevance for a compound with endocrine activity at concentrations much higher than plasma concentrations is addressed. This might be important for evaluating in silico 
results, such as in this study, but might not be of concern biologically. On the other hand, the inactivity of a compound at plasma concentrations in short-term exposure studies (e.g., in screening assays in the Tox21 program) is not an indication that the compound does not lead to adverse effects long-term. Hence, if the mechanism of action of EDCs, i.e., binding to nuclear receptors, is predicted or seen in vitro, such compounds should undergo further evaluation of long-term endocrine adverse effects. This is especially important for drugs where exposure is higher than with other groups of EDCs. Based on our results and a certain extent of structure similarity in ATC groups, special emphasis should be put on novel tyrosine kinase inhibitors, antidepressants, and benzodiazepine-type anxiolytics or hypnotics and sedatives. Regarding the development of alternative methods for the identification of EDCs among drugs, efforts should be made to better evaluate AR-, ER $\alpha$-, and ER $\beta$-mediated adverse effects, as these nuclear receptors were most frequently affected in this study.

\section{Materials and Methods}

\subsection{Database Preparation}

The NIH (National Institutes of Health) NCATS Inxight: Drugs portal (version 1.1, NCATS, Bethesda, MD, USA) was used to create a database of marketed US-approved drugs, freely available at https://drugs.ncats.io/ [11]. Both over-the counter and prescription drugs were considered. The portal encompasses data on US-approved drugs from the following sources: DailyMed, Drugs@FDA, OrangeBook, and Code of Federal Regulations Title 21-Over-the-Counter Drugs. Only entries with "chemical" and "substance Class" were used, while proteins, mixtures, polymers, nucleic acids, and structurally diverse drugs were filtered out. Additionally, due to the prerequisites of computational tools ED and VTL, compounds with molar masses below 60 and above $600 \mathrm{~g} / \mathrm{mol}$ were removed from the database.

\subsection{Docking with ED}

The ED docking program (National Institute of Chemistry, Ljubljana, Slovenia) was used to estimate the binding affinities of drugs to 12 nuclear receptors: AR, ER $\alpha, E R \beta, G R, L X R \alpha, L X R \beta$, PPAR $\alpha, \operatorname{PPAR} \beta, \operatorname{PPAR} \gamma, \mathrm{RXR} \alpha, \mathrm{TR} \alpha$, and $\mathrm{TR} \beta$. For four receptors (AR, ER $\alpha, E R \beta$, and GR), both agonist and antagonist conformations were considered. For the docking simulation, Docking Interface for Target Systems (DoTS) was used, while the docking calculation for drugs docked in a receptor's ligand binding domain was done with AutoDock Vina. Receptor structures in the ED were validated with a database of active compounds, a database of compounds that have an agonist mode of action, and of a database that has an antagonist mode of action for each receptor. Based on the area-under-curve (AUC) evaluation of the receiver operating characteristic (ROC) curve (where sensitivity is plotted against 1 minus specificity), three threshold values of binding free energies were determined for each receptor. Thresholds translate to color-coded output results of the program: green corresponds to a low probability of binding (sensitivity $>0.75)$, yellow $(0.5<$ sensitivity $<0.75)$ and orange $(0.25<$ sensitivity $<0.5$ ) correspond to a medium probability of binding, and red (sensitivity $<0.25$ ) corresponds to a high probability of binding. Limitations for the compounds submitted to the ED are: molecular weight over $600 \mathrm{~g} / \mathrm{mol}$, multiple ionization of a compound, and boron-containing compounds. The program is a freely accessible web interface at http://endocrinedisruptome.ki.si/, and receptor structures prepared for docking are available for download as pdbqt files [12].

\subsection{Docking with VTL}

VirtualToxLab platform (version 5.8, Biographics Laboratory 3R, Basel, Switzerland) for estimating the toxic potential of compounds was used to predict the interactions of drugs with nuclear receptors for a subset of drugs with ED-predicted strong binding to a nuclear receptor and that do not target a nuclear receptor as a pharmacological mode of action. An intersection of receptors available in both the ED and VTL was considered: AR, ER $\alpha, E R \beta, G R, \operatorname{LXR} \alpha, \operatorname{PPAR} \gamma, \mathrm{TR} \alpha$, and $\mathrm{TR} \beta$. For an 
ED-predicted drug-receptor interaction in the subset of the drugs, the interaction with the respective receptor was assayed with VTL. The program evaluates the binding affinity by automated, flexible docking with Yeti/AutoDock. This provides for the assessment of all orientations and conformations of small molecules in the binding site. Additionally, VTL uses a multidimensional QSAR process using the mQSAR software (Quasar), which considers orientation, position, different solvation, protonation, conformation, induced-fit models, and the tautomeric state of the small molecules. As a result, the data are provided as concentrations at which the compounds are predicted to interact with a nuclear receptor. If no interaction is predicted or the concentration of interaction would be higher than 100 $\mu \mathrm{M}$, the program returns "not binding" as a result. The program was developed by Biographics Laboratory 3R, and its license is freely accessible for universities and nonprofit organizations, as well as governmental agencies, at http://www.biograf.ch/ [13,14].

\subsection{Tox21 Dataset Retrieval}

The Toxicology in the 21st Century (Tox21) program aims at the developing and evaluating of high-throughput screening methods for toxicological risk assessment. It is a product of collaboration of the EPA, National Toxicology Program (NTP), NCATS, and the Food and Drug Administration (FDA). Tox21 data on screening of more than 10,000 compounds in cell-based assays are publicly available. Activities of several transcription factors in gene reporter assays were tested upon exposure to compounds in the Tox 21 database, assays for the activation of some endocrine nuclear receptors among them. An intersection of receptors available in both the ED and Tox21 database was considered: AR, ER $\alpha, \mathrm{GR}, \mathrm{RXR} \alpha, \mathrm{PPAR} \gamma$, and TR. Tox 21 data visualization tool Tox 21 activity profiler (beta version, National Institute of Environmental Health Sciences, Durham, NC, USA) was used to access the data available at https://sandbox.ntp.niehs.nih.gov/tox21-activity-browser/ [15-17]. A list of CAS numbers of the subset of prioritized drugs was submitted to the tool. Activity due to cytotoxicity for antagonist-type calls was excluded. For an ED-predicted drug-receptor interaction in the subset of the drugs, interactions with the respective receptors were considered positive for AR if activity was seen in any of the following assays: tox21-ar-bla-agonist-p1, tox21-ar-bla-antagonist-p1, tox21-ar-mda-kb2-luc-agonist-p1, tox21-ar-mda-kb2-luc-antagonist-p1, or tox21-ar-mda-kb2-luc-antagonist-p2; for ER $\alpha$, if activity was seen in any of the following assays: tox21-er-bla-agonist-p2, tox21-er-bla-antagonist-p1, tox21-er-luc-bg1-4e2-agonist-p2, tox21-er-luc-bg1-4e2-antagonist-p1, or tox21-er-luc-bg1-4e2-antagonist-p2; for GR, if activity was seen in any of the following assays: tox21-gr-hela-bla-agonist-p1 or tox21-gr-hela-bla-antagonist-p1; for $R X R \alpha$, if activity was seen in the tox21-rxr-bla-agonist-p1 assay; for $\operatorname{PPAR} \gamma$, if activity was seen in the tox21-pparg-bla-agonist-p1 or tox21-pparg-bla-antagonist-p1 assays; and for TR, if activity was seen in the tox21-gh3-tre-agonist-p1 or tox21-gh3-tre-antagonist-p1 assays. Inconclusive results (where activity is at a concentration higher than $100 \mu \mathrm{M}$ ) were deemed as negative results.

\subsection{Cell-Based Assays}

The MDA-kb2 cell line (purchased from the American Type Culture Collection, Manassas; VA, USA, refence number CRL-2713) and AR-EcoScreen cell line (purchased from the Japanese Collection of Research Bioresources Cell Bank, Ibaraki, Japan, reference number JCRB1328) were used for cell-based assays. The MDA-kb2 cell line was derived from the MDA-MB-453 human breast cancer cell line by stable transfection with the firefly luciferase gene controlled by a glucocorticoid-inducible promoter [24]. The MDA-kb2 were maintained in Leibovitz's L-15 medium (Sigma-Aldrich, Saint Louis, MO, USA), supplemented with 10\% dextran-charcoal-stripped fetal bovine serum (Gibco, Thermo Fisher Scientific, Waltham, MA, USA), $100 \mathrm{U} / \mathrm{mL}$ penicillin (Sigma-Aldrich), and $100 \mu \mathrm{g} / \mathrm{mL}$ streptomycin (Sigma-Aldrich). Antagonist assay with MDA-kb2 was performed as previously described by Kolšek et al. [25]. AR-EcoScreen is an OECD-validated cell line that was derived from the Chinese hamster ovary (CHO-K1) cell line by stable transfection with a human androgen receptor, firefly luciferase gene controlled by an androgen-inducible promoter, and a constitutively expressed sea pansy luciferase gene. 
AR-EcoScreen were maintained in phenol-red-free Dulbecco's modified Eagle's medium (DMEM)/F-12 (Gibco), supplemented with 5\% fetal bovine serum (Gibco), $200 \mu \mathrm{g} / \mathrm{mL}$ zeocin (InvivoGen, Toulouse, France), $100 \mu \mathrm{g} / \mathrm{mL}$ hygromycin (Sigma-Aldrich), $100 \mathrm{U} / \mathrm{mL}$ penicillin (Sigma-Aldrich), and $100 \mu \mathrm{g} / \mathrm{mL}$ streptomycin (Sigma-Aldrich). All experiments with AR-EcoScreen were performed according to the OECD test guideline 458 [20]. Irinotecan (CAS 100286-90-6) and palonosetron (CAS 135729-61-2) were purchased from Alfa Aesar (Ward Hill, MA, USA) and Tokyo Chemical Industry (Tokyo, Japan), respectively. Hydrocortisone (CAS 50-23-7), dihydrotestosterone (CAS 521-18-6), and DMSO (CAS 67-68-5) were purchased from Sigma-Aldrich.

\section{Conclusions}

While assessing if a compound fulfills the WHO criteria for EDCs and "alters function(s) of the endocrine system and consequently causes adverse effects" is a very complex task; evaluating a molecular interaction between a compound and a nuclear receptor is not [3]. Hence, we expect binding to nuclear receptors will often be defined as a molecular initiating event in AOPs yet to be developed for EDCs and, consequently, used in toxicological screening assays of compounds.

In light of the novel European Medicines Agency draft guidelines that require data on the endocrine activity of drugs submitted for approval, we propose that already-approved drugs are assessed in the same manner. Based on the computational evaluation done here, we suggest prioritized drugs for such assessments.

Supplementary Materials: The following are available online at http:/www.mdpi.com/1420-3049/25/7/1616/s1: Table S1: 1046 US-approved and marketed drugs with Endocrine Disruptome (ED)-predicted binding to respective nuclear receptors and Table S2: Structure_information.pdf.

Author Contributions: Conceptualization, M.K. and M.S.D.; methodology, M.K. and M.S.D.; validation, M.K.; formal analysis, M.K.; investigation, M.K and M.S.D.; resources, M.S.D.; data curation, M.K.; writing—original draft preparation, M.K.; writing—review and editing, M.S.D.; visualization, M.K.; supervision, M.S.D.; project administration, M.S.D.; and funding acquisition, M.S.D. All authors have read and agreed to the published version of the manuscript.

Funding: This research was funded by a young researcher grant from the Slovenian Research Agency to M. Kenda and the Slovenian Research Agency program group "Medicinal Chemistry: Drug Design, Synthesis and Evaluation of the Drugs", program code P1-0208.

Acknowledgments: The authors thank A. Pungartnik, MLitt for English editing of the manuscript.

Conflicts of Interest: The authors declare no conflicts of interest. The funders had no role in the design of the study; in the collection, analyses, or interpretation of data; in the writing of the manuscript; or in the decision to publish the results.

\section{References}

1. Diamanti-Kandarakis, E.; Bourguignon, J.-P.; Giudice, L.C.; Hauser, R.; Prins, G.S.; Soto, A.M.; Zoeller, R.T.; Gore, A.C. Endocrine-disrupting chemicals: an Endocrine Society scientific statement. Endocr. Rev. 2009, 30, 293-342. [CrossRef] [PubMed]

2. Kavlock, R.J.; Daston, G.P.; DeRosa, C.; Fenner-Crisp, P.; Gray, L.E.; Kaattari, S.; Lucier, G.; Luster, M.; Mac, M.J.; Maczka, C.; et al. Research needs for the risk assessment of health and environmental effects of endocrine disruptors: a report of the U.S. EPA-sponsored workshop. Environ. Health Perspect. 1996, 104, 715-740. [CrossRef] [PubMed]

3. WHO. Global assessment of the state-of-the-science of endocrine disruptors. In WHO/PCS/EDC/02.2; WHO: Geneva, Switzerland, 2013.

4. Trasande, L. Stand firm on hormone disruptors. Nature 2016, 539, 469. [CrossRef] [PubMed]

5. Allen, T.E.H.; Goodman, J.M.; Gutsell, S.; Russell, P.J. Defining molecular initiating events in the adverse outcome pathway framework for risk assessment. Chem. Res. Toxicol. 2014, 27, 2100-2112. [CrossRef] 
6. The Adverse Outcome Pathways development programme workplan - OECD. Available online: https: //www.oecd.org/chemicalsafety/testing/projects-adverse-outcome-pathways.htm (accessed on 9 March 2020).

7. aus der Beek, T.; Weber, F.A.; Bergmann, A.; Hickmann, S.; Ebert, I.; Hein, A.; Küster, A. Pharmaceuticals in the environment-Global occurrences and perspectives. Environ. Toxicol. Chem. 2016, 35, 823-835. [CrossRef]

8. Huerta, B.; Rodriguez-Mozaz, S.; Lazorchak, J.; Barcelo, D.; Batt, A.; Wathen, J.; Stahl, L. Presence of pharmaceuticals in fish collected from urban rivers in the U.S. EPA 2008-2009 National Rivers and Streams Assessment. Sci. Total Environ. 2018, 634, 542-549. [CrossRef]

9. Santos, L.H.M.L.M.; Araújo, A.N.; Fachini, A.; Pena, A.; Delerue-Matos, C.; Montenegro, M.C.B.S.M. Ecotoxicological aspects related to the presence of pharmaceuticals in the aquatic environment. J. Hazard. Mater. 2010, 175, 45-95. [CrossRef]

10. Committee for Medicinal Products for Human Use (CHMP); European Medicines Agency. Guideline on the environmental risk assessment of medicinal products for human use Draft. In EMEA/CHMP/SWP/4447/00; Committee for Medicinal Products for Human Use (CHMP): Amsterdam, The Netherlands, 2018.

11. NCATS Creates Drug Development Data Portal | National Center for Advancing Translational Sciences. Available online: https://ncats.nih.gov/pubs/features/ncats-inxight-drugs (accessed on 10 March 2020).

12. Kolšek, K.; Mavri, J.; Sollner Dolenc, M.; Gobec, S.; Turk, S. Endocrine Disruptome-An Open Source Prediction Tool for Assessing Endocrine Disruption Potential through Nuclear Receptor Binding. J. Chem. Inf. Model. 2014, 54, 1254-1267. [CrossRef]

13. Vedani, A.; Dobler, M.; Smie, M. VirtualToxLab - A platform for estimating the toxic potential of drugs, chemicals and natural products. Toxicol Appl Pharmacol. 2012, 261, 142-153. [CrossRef]

14. Vedani, A.; Smiesko, M.; Spreafico, M.; Peristera, O.; Dobler, M. VirtualToxLab ${ }^{\mathrm{TM}}$ - In silico prediction of the toxic (endocrine-disrupting) potential of drugs, chemicals and natural products. Two years and 2,000 compounds of experience: A progress report. ALTEX 2009, 26, 167-176. [CrossRef]

15. Tice, R.R.; Austin, C.P.; Kavlock, R.J.; Bucher, J.R. Improving the human hazard characterization of chemicals: A Tox21 update. Environ. Health Perspect. 2013, 121, 756-765. [CrossRef] [PubMed]

16. Thomas, R.S.; Paules, R.S.; Simeonov, A.; Fitzpatrick, S.C.; Crofton, K.M.; Casey, W.M.; Mendrick, D.L. The US Federal Tox21 Program: A strategic and operational plan for continued leadership. ALTEX 2018, 35, 163-168. [CrossRef] [PubMed]

17. Kavlock, R.J.; Austin, C.P.; Tice, R.R. Toxicity testing in the 21st century: Implications for human health risk assessment. Risk Anal. 2009, 29, 485-487. [CrossRef] [PubMed]

18. Andersson, N.; Arena, M.; Auteri, D.; Barmaz, S.; Grignard, E.; Kienzler, A.; Lepper, P.; Lostia, A.M.; Munn, S.; Parra Morte, J.M.; et al. Guidance for the identification of endocrine disruptors in the context of Regulations (EU) No 528/2012 and (EC) No 1107/2009. EFSA J. 2018, 16. [CrossRef]

19. Test, No. 455: Performance-Based Test Guideline for Stably Transfected Transactivation In Vitro Assays to Detect Estrogen Receptor Agonists and Antagonists. OECD Guidelines for the Testing of Chemicals, Section 4. OECD 2016. [CrossRef]

20. Test, No. 458: Stably Transfected Human Androgen Receptor Transcriptional Activation Assay for Detection of Androgenic Agonist and Antagonist Activity of Chemicals. OECD Guidelines for the Testing of Chemicals, Section 4. OECD 2016. [CrossRef]

21. Chen, S.; Zhou, D.; Hsin, L.-Y.; Kanaya, N.; Wong, C.; Yip, R.; Sakamuru, S.; Xia, M.; Yuan, Y.-C.; Witt, K.; et al. AroER tri-screen is a biologically relevant assay for endocrine disrupting chemicals modulating the activity of aromatase and/or the estrogen receptor. Toxicol. Sci. 2014, 139, 198-209. [CrossRef]

22. Braeuning, A. Firefly luciferase inhibition: a widely neglected problem. Arch. Toxicol. 2015, 89, 141-142. [CrossRef]

23. Auld, D.S.; Thorne, N.; Nguyen, D.T.; Inglese, J. A specific mechanism for nonspecific activation in reporter-gene assays. ACS Chem. Biol. 2008, 3, 463-470. [CrossRef]

24. Wilson, V.S.; Bobseine, K.; Lambright, C.R.; Gray, L.E. A novel cell line, MDA-kb2, that stably expresses an androgen- and glucocorticoid-responsive reporter for the detection of hormone receptor agonists and antagonists. Toxicol. Sci. 2002, 66, 69-81. [CrossRef] 
25. Kolšek, K.; Gobec, M.; Mlinarič Raščan, I.; Sollner Dolenc, M. Screening of bisphenol A, triclosan and paraben analogues as modulators of the glucocorticoid and androgen receptor activities. Toxicol. Vitr. 2014, 29, 8-15. [CrossRef] [PubMed]

(9) 1 (C) 2020 by the authors. Licensee MDPI, Basel, Switzerland. This article is an open access article distributed under the terms and conditions of the Creative Commons Attribution (CC BY) license (http://creativecommons.org/licenses/by/4.0/). 